\title{
Orthomene (Menispermaceae) in the Brazilian Amazon
}

\author{
Julio dos Santos de SOUSA (orcid.org/0000-0003-1291-374X) ${ }^{*}$ Ely Simone Cajueiro GURGEL, \\ Maria de Nazaré do Carmo BASTOS \\ Museu Paraense Emílio Goeldi, Programa de Capacitação Institucional (PCI/MPEG), Coordenação de Botânica, Av. Perimetral 1901, Terra Firme, 66040-170, Belém \\ Pará, Brasil. \\ * Corresponding author: jssousa27@yahoo.com.br
}

\section{ABSTRACT}

Orthomene comprises four species distributed from Central to South America, of which three occur in phytogeographic domains of Brazil. In Brazil, Amazonia is the main center of diversity for the genus. This work is a taxonomic treatment of Orthomene in Brazil and involved analyzing field collections (between January 2017 and July 2018), types and botanical specimens from 32 national and foreign herbaria. The three species in the study area are Orthomene hirsuta, Orthomene prancei and Orthomene schomburgkii. The latter is the most common and widely distributed species of the genus in the country. An identification key, descriptions, illustrations, distribution data, and additional comments for each species are provided.

KEYWORDS: Anomospermeae, botany, Menispermoideae, taxonomy

\section{Orthomene (Menispermaceae) na Amazônia brasileira RESUMO}

Orthomene possui quatro espécies, distribuídas desde a América Central até a América do Sul, sendo que três ocorrem nos domínios fitogeográficos brasileiros. No Brasil, a Amazônia brasileira é considerada o principal centro de diversidade do gênero. O tratamento taxonômico envolveu a análise de material coletado (entre janeiro de 2017 e julho de 2018), tipos e amostras dos espécimes de Orthomene depositados em 32 herbários nacionais e estrangeiros. O gênero está representado na área de estudo por três espécies: Orthomene hirsuta, Orthomene prancei e Orthomene schomburgkii, sendo esta última a mais comum e amplamente distribuída nas regiôes brasileiras de sua ocorrência. São apresentadas uma chave de identificação, descriçôes e ilustraçóes das espécies, bem como dados adicionais sobre distribuição geográfica e comentários sobre as mesmas.

PALAVRAS-CHAVE: Anomospermeae, botânica, Menispermoideae, taxonomia

\section{INTRODUCTION}

The tribe Anomospermeae Miers comprises 13 genera and 80 species distributed in South and Central America, Indo-Malesia, New Caledonia, Australia, and East Asia (Ortiz et al. 2016). These authors place the genus Orthomene Barneby \& Krukoff within this tribe and subfamily Menispermoideae Arn.

Orthomene was described by Barneby and Krukoff in 1971, was segregated from Anomospermum based on fruit and seed characters, and is easy to recognize because of the apical style scar on the fruit, linear endocarp and endosperm, and straight embryo (Sousa 2016). In flower, however, it is almost indistinguishable from Anomospermum. According to Wefferling et al. (2013), the style scar at the fruit apex of Orthomene is an exception among Menispermoideae (basal or subbasal scar) and Anomospermeae (usually basal scar). Despite this, tribe Anomospermeae is monophyletic with strong support, although Orthomene is polyphyletic (Jacques et al. 2011). This corroborates previous studies by Ortiz et al. (2007) and Jacques (2009), who demonstrated that the type of endocarp is a phylogenetically significant character to separate taxa.
Orthomene possesses four species (Ortiz et al. 2016) distributed from Central America (Panama and Trinidad and Tobago) to South America, where it occurs in Bolivia, Brazil, Colombia, Ecuador, Guyana, French Guiana, Peru, Suriname and Venezuela (Barneby and Krukoff 1971; Tropicos 2018; Ortiz 2011; Teixeira and Amorim 2012). In Brazil, the genus is represented by three species distributed in the northern, northeastern, central-western, and southeastern regions (CRIA 2018; Sousa 2016), in the Amazon, Caatinga, Cerrado, Atlantic Forest, and Pantanal phytogeographic domains (Braga 2018). Within Brazil, Amazonia is considered the center of species diversity for the genus. Studies of Orthomene include taxonomic treatments of local floras and protected areas (Teixeira and Amorim 2012; Sothers et al. 1999), which generally include only a few species (Sousa 2016).

Although morphological characters have been used to separate the taxa of Orthomene (Barneby and Krukoff 1971), the morphological delimitation in this genus is very complex, resulting in confusion among species and with other genera, with the genus commonly being misidentified as Anomospermum. Based on this, Ortiz et al. (2016) noted the 
need for more comprehensive sampling to better understand the taxonomy of the genus.

The objective of this study was to produce a taxonomic treatment of Orthomene in the Brazilian Amazon, which better identifies the species and advances what is known about the genus in the Neotropics.

\section{MATERIAL AND METHODS}

The study was conducted using recently collected specimens and material archived at the following herbaria: HERBAM, HUEFS, MG, IAN, INPA, NY, R, RB, S, and UFMT (abbreviations according to Thiers 2018). We conducted field trips between January 2017and July 2018 in order to collect fertile specimens in the Brazilian Amazon (states of Acre, Amapá, Amazonas, Maranhão, Mato Grosso, Pará, Rondônia, Roraima and Tocantins), in the rainy and dry seasons. The specimens were described and illustrated with the aid of a stereomicroscope (Leica EZ4D). Morphological terms follow Hickey (1973), Radford et al. (1974), Rizzini (1977), Weberling (1992), and Barroso et al. (1999). Species identification is based on examination of types, keys, and the literature. The species descriptions are based on the material studied. The following abbreviations are used: fl (flower), fr (fruit), and sn (without a number).

\section{RESULTS}

Orthomene Barneby \& Krukoff, Mem. New York Bot. Gard. 22(2): 79-80. 1971.

Scandent shrubs or lianas, $0.4-11 \mathrm{~cm}$ diameter; rhytidome brown to greyish, young branches fissured or smooth, hirsute, tomentose, strigose or glabrous. Leaves alternate, basifixed; venation basal or suprabasal actinodromous; primary veins 3 palmatinerved or plinerved; petiole cylindrical, with or without swollen pulvinus. Inflorescences in botrya, panicles, simple racemes, or solitary flowers, supra-axillary and/or ramiflorous. Flowers dichlamydeous; sepals 6-9, biseriate or triseriate; petals six, equal to or shorter than stamens, fleshy, involute, forming a pseudodisc around each stamen. Staminate flowers with six stamens, filaments free or connate at basal insertion; anther dehiscence collateral or longitudinal. Pistillate flowers with one ovule per carpel; stigma apical. Drupes solitary, in pairs or grouped in threes in an infructescence; style scar apical; epicarp coriaceous; mesocarp mucilaginous, thin, or not observed; endocarp linear, crustaceous or woody; seed linear, endosperm ruminate; embryo straight.

Type species: Orthomene schomburgkii (Miers) Barneby \& Krukoff.

In Brazil, Orthomene is represented by three species distributed in the northeastern (states of Bahia, Ceará, Pernambuco and Sergipe), central-western (Goiás, Mato Grosso do Sul and Mato Grosso), southeastern (Espírito
Santo, Minas Gerais and Rio de Janeiro), and northern (Acre, Amazonas, Amapá, Pará, Rondônia and Roraima) regions. They occur in the Amazon, Caatinga, Cerrado, Atlantic Forest, and Pantanal phytogeographic domains (Braga 2018) and, within the country, Amazonia is the main center of diversity for the genus.

\section{Identification key to species of Orthomene in the Brazilian Amazon}

1. Sapwood orangish; petiole tomentose; leaf blade obovate, apex rounded, obtuse, or submarginate; secondary and tertiary veins prominent on the adaxial surface; anther dehiscence collateral ......

O. prancei

1. Sapwood yellowish; petiole glabrous to sparsely strigose or densely hirsute; leaf blade elliptic, lanceolate, oblong, or ovate, apex acuminate, mucronate or attenuate; secondary veins deeply impressed, flat or not apparent on the adaxial surface, tertiary veins deeply impressed or inconspicuous on the adaxial surface; anther dehiscence longitudinal.

2. Petiole densely hirsute; leaf blade bullate, sparsely hirsute on the abaxial surface, margin repand, revolute, ciliate; secondary and tertiary veins deeply impressed on the adaxial surface; bracts acicular or narrowly triangular, hirsute; sepals 6, biseriate; stigma falciform; endocarp longitudinally foveolate on the whole outer surface O. hirsuta

2. Petiole glabrous to sparsely strigose; leaf blade flat, glabrous to sparsely strigose on the abaxial surface, margin rectilinear, not revolute, not ciliate; secondary veins flat or not apparent, and tertiary veins inconspicuous on the adaxial surface; bracts ovate, deltoid, or lanceolate, sericeous; sepals 9, triseriate; stigma lobed; endocarp not foveolate on the outer surface .. O. schomburgkii

Orthomene hirsuta (Krukoff \& Moldenke) Barneby \& Krukoff, Mem. New York Bot. Gard. 22(2): 81. 1971. Figure 1.

Anomospermum hirsutum Krukoff \& Moldenke, Bull. Torrey Bot. Club 70: 401. 1943. Type: Brazil. Amazonas, Manaus, estrada do Paredáo, Ducke, A. 753 (isotypes, INPA, $\mathrm{R}, \mathrm{RB})$.

Liana, 10-17 mm diameter, scandent; rhytidome brown, young branches fissured, hirsute; sapwood yellowish, with white streaks. Petiole $0.4-2.5 \times 0.05-0.2 \mathrm{~cm}$, densely hirsute. Leaf blade 3.9-14.1 × 1.5-7.8 cm, elliptic, lanceolate or ovate, chartaceous to subcoriaceous, bullate, glabrous to sparsely hirsute on the adaxial surface and sparsely hirsute on the abaxial surface; apex acuminate or mucronate; base cuneate or obtuse; margin repand, revolute, ciliate. Venation basal actinodromous, primary veins 3-palmatinerved; secondary veins deeply impressed on the adaxial surface; tertiary veins reticulate, deeply impressed on the adaxial 

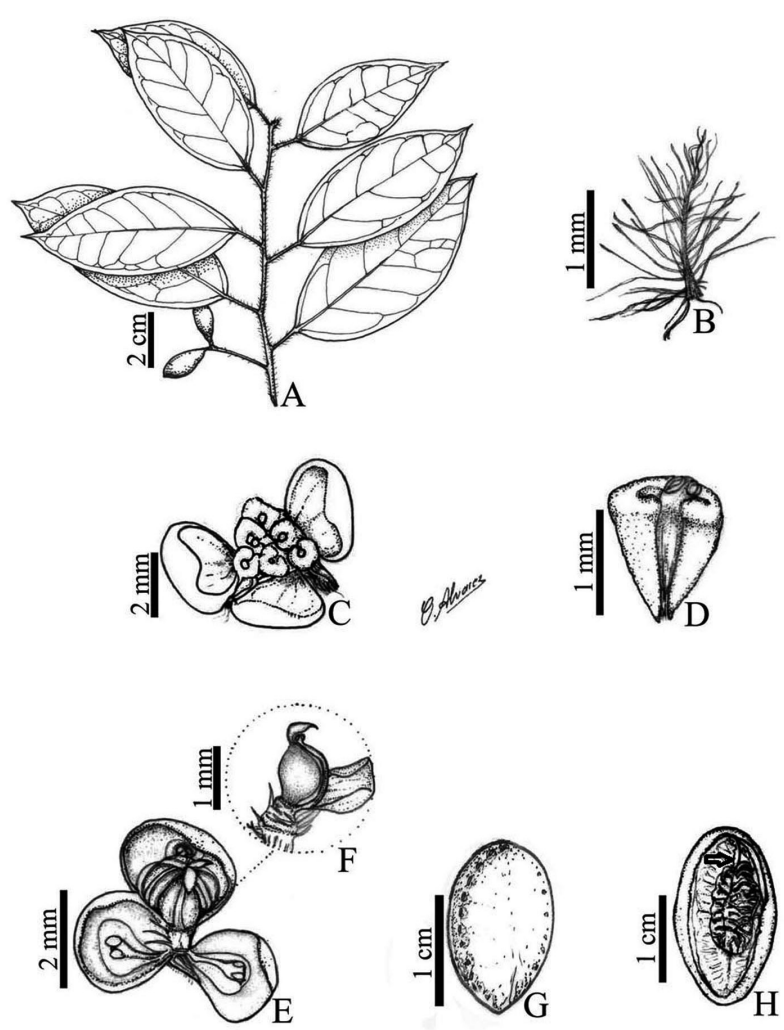

Figure 1. Orthomene hirsuta. A. Branch. B. Bract. C. Staminate flower. D. Involute petal and stamen. E. Pistillate flower. F. Detail of flower showing the Carpel. G. Endocarp longitudinally foveolate on outer surface. H. Endocarp in longitudinal section showing the endosperm and the condyle.

surface. Inflorescences in simple racemes, panicles or solitary flower, supraxillary, ramiflorous. Inflorescence bracts $0.5-2.5$ $\times 0.25-0.5 \mathrm{~mm}$, acicular or narrowly triangular, hirsute. Sepals 6, biseriate, 1-6 × 0.3-5.5 mm, deltoid, lanceolate, narrowly triangular, suborbicular or widely elliptic, glabrous or hirsute; petals $1-3 \times 1.9-2.9 \mathrm{~mm}$, obdeltoid, cucullate, glabrous. Staminate flowers: filaments free, glabrous, anthers longitudinally dehiscent. Pistillate flowers: staminodes 1.5-3 $\mathrm{mm}$ long, linear, glabrous; ovary $0.7-2.5 \mathrm{~mm}$ long, ellipsoid or turbinate, glabrous; stigma falciform. Drupes 1.5-2 × 0.6-1.1 $\mathrm{cm}$, ellipsoid, obovoid or subglobous, yellow to orangish when mature, glabrous; endocarp longitudinally foveolate on outer surface.

Distribution: Orthomene hirsuta is distributed in Venezuela, Peru, and Brazil. In Brazil it occurs in the states of Acre, Amazonas, and Pará (Barneby 2001; Braga 2018; Tropicos 2018). In Brazil it is most common in terra firme forest, as cited by Barneby (2001).

Examined specimens. BRAZIL. Acre: Mâncio Lima, estrada do Isaco, 25 Nov 2001, [fr], T. B. Croat 85740 (NY, RB). Amazonas: Cucuí, 20 Nov1941, [fr], R.L. Fróes 12408 (NY); Manaus, estrada do Paredão, 14 Jun 1941, [f], A. Ducke 753 (INPA, NY, R, RB); Manaus, em direção nordeste de
Flores, 21 Dec 1945, [f], A. Ducke 1804 (IAN, MG, RB); Manaus-Itacoatiára, Reserva Florestal Adolpho Ducke, Igarapé do Tinga, 08 Dec 1994, [fr], A. Vicentini et al. 801 (MG); São Gabriel da Cachoeira, próximo ao rio Negro, 02 Oct 1935 , [f], Ducke, A. s.n. (NY, RB); São Gabriel da Cachoeira, rio Uaupés, próximo ao porto Juquira, 13 Oct 1944, [f], R. L. Fróes 21154 (NY); São Gabriel, próximo ao rio Negro, $30 \mathrm{Apr}$ 1948, [f]], G. A. Black 2473 (IAN); São Paulo de Olivença, perto da estrada para Bonfim, 16 Aug 1973, [f \& fr], E. Lleras et al. 17349 (INPA, MG, NY, R, S). Pará: rodovia CuiabáSantarém, km 1225, 21 Nov 1977, [fr], G. T. Prance et al. 25604 (MG, NY).

Orthomene hirsuta has been collected with flowers in April, June, August, October and December, and with fruits in February, May, August, October and December.

Orthomene prancei Barneby \& Krukoff, Mem. New York Bot. Gard. 22(2): 81-82. 1971. Type: Brazil. Amazonas: bacia do Rio Urubu. Prance, G. T. et al. 5011 (holotype, NY; isotype, INPA). Figure 2.

Liana, 4-6 $\mathrm{mm}$ diameter, voluble; rhytidome brown, young branches fissured, tomentose; sapwood orangish. Petiole $0.6-1.5 \times 0.1-0.2 \mathrm{~cm}$, tomentose. Leaf blade 5-8.9 $\times$ $2.5-5.5 \mathrm{~cm}$, obovate, subcoriaceous, flat, tomentose on both surfaces; apex rounded, obtuse or submarginate; base cuneate
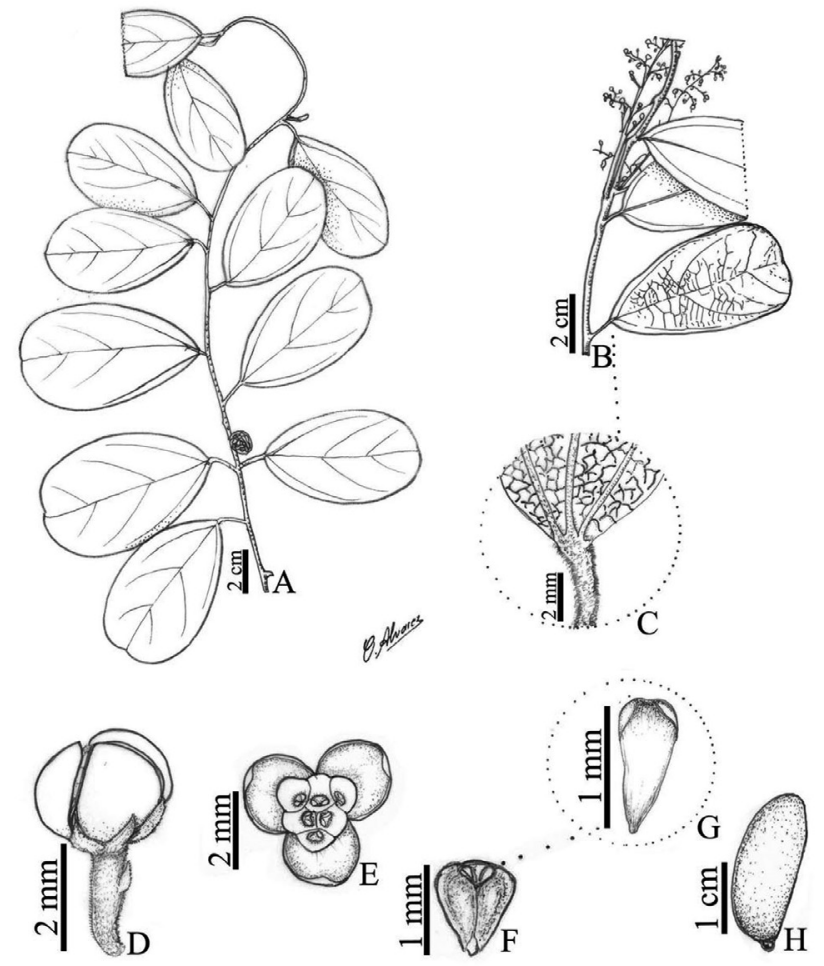

Figure 2. Orthomene prancei. A. Fruitful branch. B. Floriferous branch. C. Detail of leaf base showing the venation. D. Flower bud. E. Staminate flower. F. Involute petal and stamen.G. Stamen. H. Drupe 
or obtuse; margin repand, revolute, not ciliate. Venation basal actinodromous, primary veins 3-palmatinerved; secondary veins prominent on the adaxial surface; tertiary veins reticulate, prominent on the adaxial surface. Inflorescences in simple racemes, panicles or solitary flower, supraxillary. Inflorescence bracts $0.5-2 \times 0.5-1 \mathrm{~mm}$, deltoid, lanceolate or ovate, sericeous. Sepals 9, triseriate, 0.5-3.8 $\times 0.3-3.6 \mathrm{~mm}$, lanceolate, oblong, ovate or suborbicular, glabrous; petals $0.9-2.5 \times 1-3 \mathrm{~mm}$, obdeltoid or obovate, glabrous. Staminate flowers: filaments connate only at the basal point of insertion, glabrous, anthers dehiscence collateral. Pistillate flowers not seen. Drupes 1.8-2.4 × 1-1.3 cm, oblongoid, greenish when immature, glabrous or strigose; endocarp longitudinally foveolate on the outer surface.

Distribution: This species is distributed in French Guiana and Brazil. In Brazil it occurs only in the state of Amazonas (Barneby 2002; Barneby and Krukoff 1971; Braga 2018; Tropicos 2018). As mentioned by Barneby (2002), it is found only in terra firme forest.

Examined specimens. Brazil. Amazonas: bacia do Rio Urubu, 06 Jun 1968, [fr], G. T. Prance et al. 5011 (INPA, NY); Novo Airão, Parque Nacional do Jaú, Campina do Patauá, 02 Sep 1998, [f], A. Vicentini et al. 1355 (INPA).

Additional specimens examined: French Guiana.SaintLaurent-du-Maroni: Vicinity of Saül, ca. $10 \mathrm{Km} \mathrm{NW}$ from Eaux Claires, between base camp and inselberg, 13 Aug 1993, [fl], S. A. Mori et al. 23263 (NY).

This species has been collected with flowers in June and with fruits in September.

Orthomene schomburgkii (Miers) Barneby \& Krukoff, Mem. New York Bot. Gard. 22(2): 80-81. 1971. Figure 3.

Anomospermum schomburgkii Miers, Contr. Bot. 3: 71-72. 1871. Type: Guiana. Schomburgk, R. 833 (holotype, photo MO; isotypes, NY, photos BM, P).

Liana, $0.5-11 \mathrm{~mm}$ diameter; rhytidome brown to greyish, young branches fissured or smooth, glabrous or sparsely strigose; sapwood yellowish. Petiole $0.5-2 \times 0.05-0.2 \mathrm{~cm}$, glabrous to sparsely strigose. Leaf blade $4.7-12.8 \times 1.5-5.2$ $\mathrm{cm}$, elliptic, oblong, lanceolate or ovate, chartaceous or coriaceous, flat, glabrous or sparsely strigose on both surfaces; apex acuminate or attenuate; base cuneate or obtuse; margin rectilinear, not revolute, not ciliate. Venation basal or suprabasal actinodromous, primary veins 3-palmatinerved or plinerved; secondary veins flat or not apparent on the adaxial surface; tertiary veins reticulate, inconspicuous on the adaxial surface. Inflorescences in botryum, simple racemes, panicles or solitary flower, supraxillary, ramiflorous. Inflorescence bracts $0.3-2.1 \times 0.25-0.7 \mathrm{~mm}$, deltoid, lanceolate or ovate, sericeous. Sepals 9, tirseriate, $0.4-5 \times 0.3-4.8 \mathrm{~mm}$, cucullate, deltoid, elliptic, obovate, suborbicular or ovate, glabrous

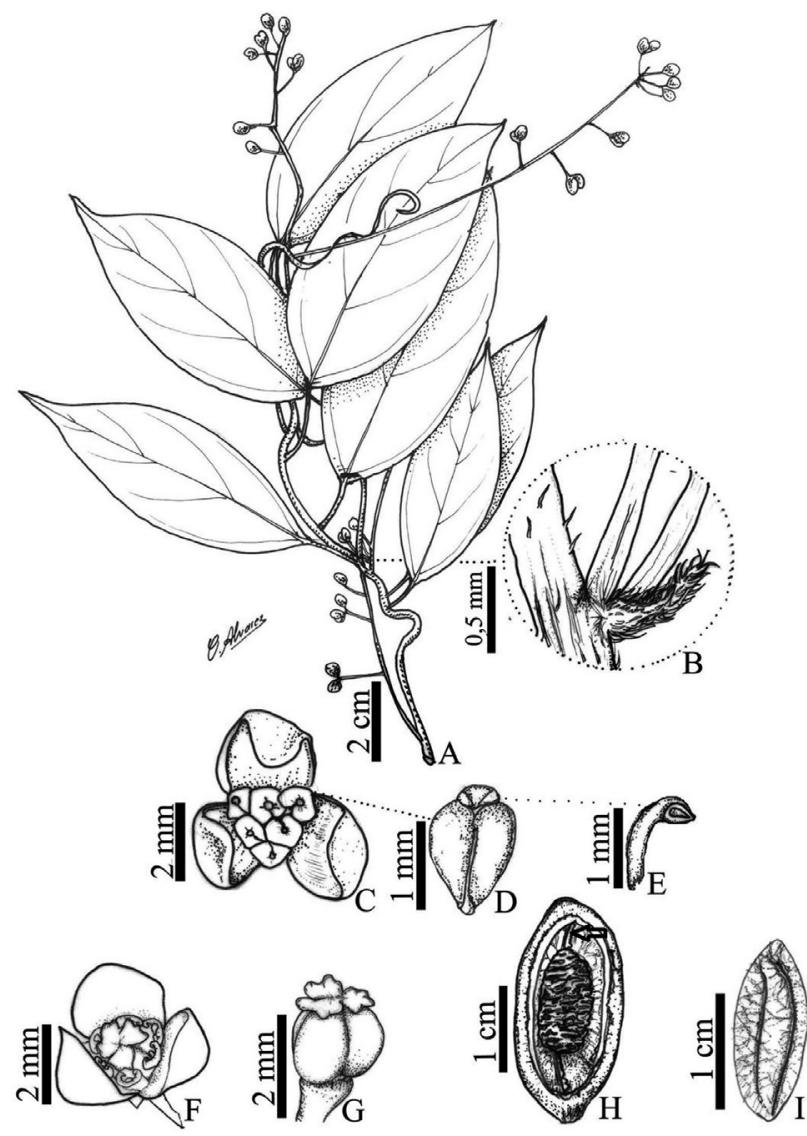

Figure 3. Orthomene schomburgkii. A. Branch. B. Bract. C. Staminate flower. D. Involute petal and stamen. E. Stamen. F. Pistillate flower. G. Gynoecium. H. Drupe in longitudinal section showing the endosperm and the condyle. I. Endocarp.

or sparsely strigose to sericeous; petals $0.4-2.5 \times 0.25-2.5$ $\mathrm{mm}$, obdeltoid, glabrous. Staminate flowers: filaments free, glabrous, anthers longitudinally dehiscent. Pistillate flowers: staminodes 1.3-1.7 mm long, linear, glabrous; ovary 0.7-2.5 $\mathrm{mm}$ long, ellipsoid or obovoid, glabrous; stigma lobed. Drupes $1.4-3.6 \times 0.9-1.7 \mathrm{~cm}$, ellipsoid or oblongoid, orangish, glabrous; endocarp not foveolate on the outer surface.

Distribution: Orthomene schomburgkii is one of the most widely distributed species of the genus and occurs in Panama, Colombia, Venezuela, Trinidad and Tobago, Guyana, Suriname, French Guiana, Ecuador, Peru, Bolivia, the Antilles, and Brazil. In Brazil it is found in the states of Acre, Amazonas, Amapá, Pará, Rondônia, Roraima, Bahia, Ceará, Pernambuco, Sergipe, Mato Grosso do Sul, Mato Grosso, Espírito Santo, Minas Gerais, and Rio de Janeiro (Barneby and Krukoff 1971; Braga 2018; Tropicos 2018; Ortiz 2011). This species is adapted to diverse environments, such as restinga, cerrado (sensu stricto), savanna, and the following forest types: terra firme, floodplain forest (várzea and igapó), riparian, seasonal, perennial hygrophilous, and dense ombrophilous (Braga 2018). 
Examined specimens. BRAZIL. Acre: Plácido de Castro, próximo ao igarpé Visionário, 05 Feb 2000, [fr], I. S. Rivero et al. 377 (NY); Rio Juruá-Mirim, próximo à Porangaba, 17 May 1971, [fl], P. J. M. Mass et al. 13073 (MG, NY). Amapá: Laranjal do Jari, ao longo do Rio Jari, 04 Jun 2010, [fr], E. S. Leal \& R. C. Forzza 248 (MG, RB); Rio Araguari, 02 Oct 1961, [f], J. M. Pires et al. 51479 (IAN, MG, NY). Amazonas: alto rio Negro, 15 Aug 1996, [fr.], P. Acevedo-Rdgz. et al. 8322 (NY); alto rio Aracá, 30 Oct 1952, [f], R. L. Fróes \& G. Addison 29190 (IAN); Barcelos, 07 Sep 1962, [f], A. P. Duarte 7166 (NY, RB); Boa Vista do Ramos, margem do rio Negro, 29 Sep 1947, [H], R. L. Fróes 22480 (IAN, NY); desembocadura do rio Uaupés, próximo à ilha das Flores, 01 May 1947, [f], J. M. Pires 340 (IAN, NY); Itapiranga, margem direita do rio Pitinga, 24 Aug 1979, [fl], C. A. Cidet al. 660 (MG, NY, RB); Lábrea, igarapé Puciari, 02 Jul 1971, [fl, G. T. Prance et al. 13866 (NY); Presidente Figueiredo, ao longo do rio Pitinga, próximo a represa de Balbina, 08 Jul 1986, [f], W. Thomas et al. 5392 (NY); rio dos Pombos, 20 Jun 1979, [fl], C. E. Calderón et al. 2629 (NY); rio Negro, próximo ao porto Curucuhy, 06 Oct 1945, [f]], R. L. Fróes 21108 (IAN, NY); rio Negro, entre as ilhas Uabetuba e da Silva, 14 Oct 1971, [fl], G. T. Prance et al. 15215 (MG, NY); rio Negro, cerca de $30 \mathrm{~km}$ acima do rio Marié, próximo à vila Macobeta, 09 Sep 1979, [f], K. Kubitzki et al. 213 (MG, $\mathrm{NY}$ ); rio Padauiri, próximo à margem do rio Negro, $07 \mathrm{Oct}$ 1947, [fl], R. L. Fróes 22554 (IAN); São Gabriel da Cachoeira, Camanaús, 30 Oct 1978, [fr], O. C. Nascimento 828 (MG, NY); São Gabriel da Cachoeira, confluência com o rio Uaupés, 17 Oct 1987, [fl], D. C. Daly et al. 5437 (MG, NY, RB); São Paulo de Olivença, 16 Aug 1973, [f], E. Lleraset al. 17310 (MG, NY); Uaupés, margem do rio Negro, 12 Oct 1962, [f], E. Oliveira 2262 (IAN). Mato Grosso: Alta Floresta, Ilha Ariosto da Riva, 16 Dec 2006, [fr], D. Sasaki 1284 (INPA, HERBAM); Juruena, margem do rio Juruena, 10 Jul 1997, [f], V. C. Souza et al. 18599 (UFMT). Pará: Juruti, 02 Jun 2014, [f], R. P. Salomáo et al. 1358 (MG); Marituba, mata da Pirelli, próximo à fazenda Uriboca, Aug 1958, [f]], J. M. Pires 7074 (IAN); Melgaço, Flona de Caxiuanã, rio Curuá, 23 Jul 2007, [f], M. M. Félix-da-Silva et al. 307 (MG); região do rio Capim, próximo ao rio Candiru-Açú, 22 Aug 1957, [fl], R. L. Fróes 33591 (IAN, NY); Santarém, margem esquerda do rio Curuá-Una, 10 Oct 2013, [fr], J. S. Sousa 555 (MG); Santarém, próximo à cachoeira do Palhão, 11 Oct 2013, [fr], J. S. Sousa 556 (MG). Rondônia: Pimenta Bueno, margem do rio Comemoração, 22 Jun 1998, [f], I. Miranda 1899 (MG); Porto Velho, margem esquerda do rio Cutia, 15 Feb 2012, [fr], G. Pereira-Silva et al. 16107 (HUEFS). Roraima: margem do rio Mucajaí, 20 Mar 1971, [fr], G. T. Prance et al. 11148 (MG, NY); margem do rio Mucajaí, 22 Mar 1971, [fr], G.T. Prance et al. 11181(MG, NY).

Flowers have been collected every month except February and April, and fruits have been collected throughout the year.

\section{DISCUSSION}

Orthomene differs from other genera of Anomospermeae by its linear endocarp and seed, apical style scar on the fruit, and straight embryo. Fruit characters were also used by Barneby and Krukoff (1971) to split the genus from Anomospermum because it is difficult to separate these taxa using vegetative characters and staminate flowers. The latter authors clearly showed that the drupe of Orthomene differs from those of Anomospermum because of its sub-asymmetric insertion on the pedicel (Figure 2H), apical style scar, ellipsoid endocarp, straight embryo, and condyle located vertically along the axis of the seed. Anomospermum has markedly asymmetric pedicel insertion, subapical style scar, endocarp curved in the shape of a "J," curved embryo, and condyle located horizontally along the axis of the seed.

Orthomene hirsuta was first described by Krukoff and Moldenke (1943) as belonging to Anomospermum. Subsequently, Barneby and Krukoff (1971) transferred Anomospermum hirsutum to Orthomene, based on fruit characters, and established the combination Orthomene hirsuta. According to the latter authors, O. hirsuta is similar to $O$. prancei, and, although these species are difficult to differentiate by the fruits, they can be easily distinguished by vegetative characters. For example, the former has an elliptic or ovate, bullate leaf blade, with an acuminate apex, and hirsute petiole, whereas the latter has an obovate, essentially flat leaf blade, with an obtuse apex, and setulose petiole. In addition to these differentiating characters, which were corroborated in the present study, we observed that $O$. hirsuta has yellowish sapwood and $O$. prance $i$ has orangish sapwood.

In addition to the vegetative characters described for $O$. hirsuta in the present treatment, $O$. prancei can be distinguished by reproductive characters that are based on two collections that can be examined (one with fruit in NY, the other with staminate flowers in the INPA herbarium). According to this material, $O$. prancei has ovate or lanceolate, sericeous inflorescence bracts, internal sepals that are not cucullate, and anthers with collateral dehiscence, whereas $O$. hirsuta has acicular or narrowly triangular, hirsute bracts, at least one cucullate internal sepal, and anthers with longitudinal dehiscence.

According to the key in Barneby and Krukoff (1971), Orthomene schomburgkii differs from the other species of the genus by its glabrous to glabrescent branches, flat leaf blade, and smooth testa of the endocarp (not foveolate). These characters overlap with those of $O$. verruculos $a$, although the subsessile fruit, strigose epicarp, and imperceptible veins on the adaxial surface distinguish $O$. verruculosa from $O$. schomburgkii, which has a fruit raised on a slender pedicel, glabrous epicarp, and conspicuous primary and secondary veins on the adaxial surface. Based on the taxonomic treatment by Ortiz (2011), O. schomburgkii differs from Anomospermum andersonii and $A$. reticulatum by the seed and embryo structure, since they are straight in the first species and cited as curved in Anomospermum. In the Brazilian specimens of $O$. schomburgkii examined in here, there were also three 
primary veins and basal or suprabasal actinodromous venation, which differs from $A$. andersonii, that has only one primary vein and eucaptodromous to brochidodromous venation. Anomospermum reticulatum subsp. reticulatum differs by having six sepals and a cleft-lipped stigma, whereas $O$. schomburgkii has nine sepals and a lobed, ligulate stigma. The latter species is easily differentiated from the other two that occur in Brazil (O. hirsuta and $O$. prancei) by the glabrous to sparsely strigose petiole, leaf blade glabrous to sparsely strigose on the abaxial surface, with a rectilinear margin, and inconspicuous secondary veins on the abaxial surface. The other species have densely hirsute to tomentose petioles, leaf blade sparsely hirsute or tomentose only on the primary veins of the abaxial surface, repand margin, and prominent secondary veins on the abaxial surface.

\section{CONCLUSIONS}

In the species studied in here, leaf and vein characters differed significantly, and were the main features used to separate the species. Orthomene schomburgkii has the widest distribution in the phytogeographic regions of Brazil, occurring from the North to the Southeast of the country. Terra firme forest was the vegetation type where the species occur most frequently.

\section{ACKNOWLEDGMENTS}

The authors thank the Conselho Nacional de Desenvolvimento Científico e Tecnológico (CNPq) for the fellowship to the first author, and the Programa de Capacitaçáo Institucional (PCI) of Museu Paraense Emílio Goeldi for the infrastructure to conduct this study.

\section{REFERENCES}

Barneby, R.C.; Krukoff, B.A. 1971. Supplementary notes on American Menispermaceae. VIII. A generic survey of the American Triclisieae and Anomospermeae. Memoirs of the New York Botanical Garden 22: 1-89.

Barneby, R.C. 2001. Menispermaceae. In: Berry, P.E.; Yatskievych, K.; Host B.K. (Ed.). Flora of the Venezuelan Guayana: LiliaceaeMyrsinaceae. Missouri Botanical Garden, St. Louis, p.554-578.

Barneby, R.C. 2002. Menispermaceae. In: Mori, S.A.; Cremers, G.; Gracie, C.A.; Granville, J.J.; Heald, S.V.; Hoff, M.; Mitchell, J.D. (Ed.). Guide to the Vascular Plants of Central French Guiana. The New York Botanical Garden Press, New York, p.474-483.

Barroso, G.M.; Morim, M.P.A.; Peixoto, L.; Ichaso, C.L.F. 1999. Frutos e sementes: morfologia aplicada à sistemática de dicotiledôneas. Universidade Federal de Viçosa, Viçosa, 443p.

Braga, J.M.A, 2018. Menispermaceae. Lista de Espécies da Flora do Brasil. Jardim Botânico do Rio de Janeiro. (http://floradobrasil. jbrj.gov.br/jabot/floradobrasil/FB163). Accessed on 27/05/2018.

CRIA. 2018. Centro de Referência e Informação Ambiental. Specieslink - simple search. (www.splink.org.br/index). Accessed on 28 May 2018.
Hickey, L.J. 1973. Classification of the arquitecture of dicotyledonous leaves. American Journal of Botany 60: 17-33.

Jacques, F.M.B. 2009.Survey of the Menispermaceae endocarps. Adansonia 31: 47-87.

Jacques, F.M.B.; Wang, W.; Ortiz, R.D.C.; Li, H.L.; Zhou, Z.K.; Chen, Z.D. 2011. Integrating fossils in a molecular-based phylogeny and testing them as calibration points for divergence time estimates in Menispermaceae. Journal of Systematics and Evolution 49: 25 - 49.

Krukoff, B.A.; Moldenke, H.N. 1943. Supplementary notes on American Menispermaceae-III. Bulletin of the Torrey Botanical Club 70: 400-405.

Ortiz, R.D.C; Kellogg, E.A.; Van Der Werff, H.2007. Molecular phylogeny of the moonseed family (Menispermaceae): Implications for morphological diversification. American Journal of Botany 94:1425-1438.

Ortiz, R.D.C. 2011. Menispermaceae. Flora Mesoamericana Tropicos. (www.tropicos.org/docs/meso/menispermaceae.pdf ). Accessed on 21 Dec 2011.

Ortiz, R.D.C.; Wang, W.; Jacques, F.M.B.; Chen, Z. 2016. Phylogeny and a revised tribal classification of Menispermaceae (moonseed family) based on molecular and morphological data. Taxon 65: 1288-1312.

Radford, A.E.; Dickison, W.C.; Massey, J.R.; Bell, C.R. 1974. Vascular plant systematics. Harper \& Row, New York, 891p.

Rizzini, C.T. 1977. Sistematização terminológica da folha. Rodriguésia 29: 103-125.

Sousa, J.S. 2016. Anomospermeae Miers (Menispermaceae) no Brasil. Doctoral thesis, Universidade Federal do Pará/Museu Paraense Emílio Goeldi, Belém, Brazil. 267p.

Sothers, C.A.; Brito, J.M.; Ortiz-Gentry, R.; Ott, C. 1999. Menispermaceae. In: Ribeiro, J.E.L.S.; Hopkins, M.J.G.; Vicentini, A.; Sothers, C.A.; Costa, M.A.S.; Brito J. M. et al. Flora da Reserva Ducke: Guia de identificação das plantas vasculares de uma floresta de terra-firme na Amazônia central. Editora INPA, Manaus, 816p.

Teixeira, M.D.R.; Amorim, A.M.A. 2012. Flora da Bahia: Menispermaceae. Sitientibus série Ciências Biológicas 12: 207-243.

Thiers B. (continuously updated). 2018. Index Herbariorum: a global directory of public herbaria and associated staff. New York, New York Botanical Garden's Virtual Herbarium. (sweetgum.nybg. org/ih/). Accessed on 28 May 2018.

Tropicos. 2018. Missouri Botanical Garden. (www.tropicos.org). Accessed on 29 May 2018.

Weberling, F. 1992.Morphology of flowers and inflorescences. Cambridge Univeristy Press, Cambridge, 405p.

Wefferling, K.; Hoot, S.B.; Neves, S.S. 2013. Phylogeny and fruit evolution in Menispermaceae. American Journal of Botany, 100: $1-23$.

RECEIVED: $23 / 07 / 2018$

ACCEPTED: 09/03/2019

ASSOCIATE EDITOR: Natalia Ivanauskas 